\title{
Bacteriological and Clinical Evaluation of 32 Cases of Diabetic Foot
}

\author{
Gülçin Güngör Olçum, ${ }^{1}$ Fidan Canan Çelik Yağan, ${ }^{2}$ Burcu Doğan, ${ }^{3}$ Sema Basat ${ }^{1}$
}

\author{
'Department of Internal Medicine, \\ University of Health Sciences \\ Ümraniye Training and Research \\ Hospital, Istanbul, Turkey \\ ${ }^{2}$ Department of Family Physicians \\ Specialists, University of Health \\ Sciences Ümraniye Training and \\ Research Hospital, Istanbul, Turkey \\ ${ }^{3}$ Departman of Family Physicians, \\ Sakarya Training and Research \\ Hospital, Sakarya, Turkey \\ Submitted: 29.03 .2016 \\ Accepted: 30.06 .2016 \\ Correspondence: \\ Gülçin Güngör Olçum \\ Ümraniye Eğitim Araştırma \\ Hastanesi, İç Hastalıkları Kliniği, \\ Istanbul, Turkey \\ E-mail: gulcin.ggo@gmail.com \\ Keywords: Bacteria; \\ CKD-EPI; diabetic foot; \\ microalbuminuria.
}

\begin{abstract}
Objective: The primary objective of the present study was to investigate clinical and laboratory characteristics of patients diagnosed with diabetic foot (DF) in order to aid in selection of antibiotic treatment and clinical follow-up. Potential relationship between DF, renal complications, and the mechanism of action of diseases were examined.
\end{abstract}

Methods: Thirty-two patients diagnosed with DF in Department of Internal Medicine between June 2014 and June 2015 were enrolled in the study. Retrospective screening of medical data was conducted and patient lipid and microalbuminuria levels, microalbumin/creatinine ratio, creatinine clearance (formulated using Chronic Kidney Disease Epidemiology Collaboration [CKD-EPI] equation), and glycated hemoglobin (HbAlc) level were recorded.

Results: Of the 32 patients diagnosed with DF, 13 were female $(40.6 \%)$ and 19 were male (59.4\%). Age range was 32 to 88 years, and mean age was $59.03 \pm 10.3$ years. Duration of disease of the patients was 5 to 40 years at time of study, and mean was $15.5 \pm 7.06$ years. Mean $\mathrm{HbAlc}$ level was $9.0 \mathrm{I} \pm 2.26 \%$ (range: $5.4-14.7 \%$ ). Mean CKD-EPI level was $75 \pm 27.34$ $\mathrm{mL} / \mathrm{min} / 1.73 \mathrm{~m} 2$ (range: $1 \mathrm{I}-130 \mathrm{~mL} / \mathrm{min} / \mathrm{I} .73 \mathrm{~m}^{2}$ ). Bacterial growth was observed in 22 cases (68.8\%), and was not detected in 10 cases (31.3\%). Two cases (6.3\%) presented with growth of multiple microorganisms.

Conclusion: Evaluation of causative microorganisms in terms of patient age and gender revealed main bacterial species found were Gram-positive cocci bacteria. There was no statistically significant difference based on CKD-EPI level in terms of mean duration $(p=0.00 \mathrm{I}$; $P<0.01$ ). Staphylococcus aureus was the most common bacteria present among cases having CKD-EPI level of $60-89 \mathrm{~mL} / \mathrm{dk}^{2} \mathrm{~m}^{2}$.

\section{INTRODUCTION}

Diabetes mellitus (DM) has both microvascular (e.g., retinopathy, nephropathy, and neuropathy), and macrovascular (e.g., coronary heart disease, peripheral vascular diseases, and cerebrovascular diseases) complications. Diabetic nephropathy (DN) predominates as critical health problem, as it leads to endstage renal failure. ${ }^{[1]}$ Microalbuminuria is defined as urinary excretion of albumin of $30-300 \mathrm{mg} / 24 \mathrm{hr}$ or $20-200 \mu \mathrm{g} / \mathrm{min}^{\left[{ }^{[2]}\right.}$ Microalbuminuria is important as an indicator of diabetic microangiopathy. ${ }^{[3]}$ Therefore, aim of present study was to determine relationship between microalbuminuria and DN in the deve- lopment of diabetic (DF), and to identify causative microorganism of DF for selection of appropriate empirical antibiotic therapy.

\section{PATIENTS AND METHODS}

A total of 32 cases diagnosed with DF at internal medicine outpatient clinics between 2014 and 2015 were included in the study. Patient data were retrieved from their medical files and retrospectively analyzed with the approval of the ethics committee. Patients without urinary tract infection, pregnancy, or diabetic renal disease were included and data related to 24-hour urinary albumin excretion rate and 
creatinine clearance, other biochemical test results, and medical examination findings were obtained from routine follow-up records.

Statistical evaluation of the study data was performed using SPSS Statistics 22.0 (IBM Corp., Armonk, NY, USA) software package. Normality of distribution was evaluated using Shapiro-Wilks test. In addition to descriptive statistical methods (mean, SD, frequency), for intergroup comparisons of quantitative data with normal distribution, one-way analysis of variance test was used. To determine which group was different, Tukey Honest Significant Difference test and Tamhane's T2 test were used. For intergroup comparisons of parameters without normal distribution, Kruskal-Wallis test was used. Student's t-test was applied to compare parameters with normal distribution, as was Mann-Whitney $U$ test, accordingly. Chi-square test and Fisher's exact test were used for qualitative data. Statistical significance was evaluated at level of $p<0.05$.

\section{RESULTS}

The study was conducted between 2014 and 2015 with total of 32 cases (female: $n=13,40.6 \%$; male: $\mathrm{n}=19,59.4 \%$; median age: 58.5 years; range: $32-88$ years) who were diagnosed and treated for DF at outpatient clinics of internal medicine (Table I).

Mean duration of diabetes was $15.5 \pm 7.06$ years (range: $5-40$ years). Mean $\mathrm{HbAIC}$ value was $9.0 \mathrm{I} \pm 2.26 \%$

Table 1. Distribution of general characteristics of the patients $(n=32)$

\begin{tabular}{|c|c|c|c|}
\hline & $\%$ & Mean \pm SD & Median (min.-max.) \\
\hline Age (years) & & & $58.5(32-88)$ \\
\hline Duration of diabetes (years) & & $15.5 \pm 7.06$ & \\
\hline Fasting blood glucose & & $207.03 \pm 78.81$ & \\
\hline Glycated hemoglobin & & $9.01 \pm 2.26$ & \\
\hline Cholesterol & & $183.22 \pm 41.22$ & \\
\hline Creatinine & & & $1.0(0.6-4.24)$ \\
\hline Albuminuria $(n=20)$ & & & $115.5(9-2785)$ \\
\hline Albuminuria/Creatinine $(n=20)$ & & & $97.3(11.7-2486)$ \\
\hline CKD-EPI (mL/min/1.73 m²) & & $75 \pm 27.34$ & \\
\hline \multicolumn{4}{|l|}{ Gender } \\
\hline Female & 40.6 & & \\
\hline Male & 59.4 & & \\
\hline \multicolumn{4}{|l|}{ Age groups } \\
\hline$<65$ years & 71.9 & & \\
\hline$\geq 65$ years & 28.1 & & \\
\hline Albuminuria analysis & 62.5 & & \\
\hline \multicolumn{4}{|l|}{ CKD-EPI group (mL/min/1.73 m²) } \\
\hline$<15$ & 3.1 & & \\
\hline $15-29$ & 3.1 & & \\
\hline $30-59$ & 21.9 & & \\
\hline $60-89$ & 40.6 & & \\
\hline$\geq 90$ & 31.3 & & \\
\hline \multicolumn{4}{|l|}{ Growth of microorganism } \\
\hline Present & 68.8 & & \\
\hline Absent & 31.3 & & \\
\hline $\begin{array}{l}\text { Patients whose antibiogram revealed } \\
\text { growth of more than } 1 \text { microorganism }\end{array}$ & 6.3 & & \\
\hline
\end{tabular}


Table 2. Distribution of microorganisms found based on gender and age groups

\begin{tabular}{|c|c|c|c|c|}
\hline Gender & Age group & Microorganism & $\mathrm{n}$ & $\%$ \\
\hline \multirow[t]{10}{*}{ Female } & \multirow[t]{4}{*}{$<65$ years } & Candida glabrata & 1 & 25 \\
\hline & & Corynebacterium striatum & 1 & 25 \\
\hline & & Serratia marcecens & 1 & 25 \\
\hline & & Staphylococcus aureus & 1 & 25 \\
\hline & \multirow[t]{6}{*}{$\geq 65$ years } & Citrobacter freundii & 1 & 12.5 \\
\hline & & Klebsialle pneumonia & 1 & 12.5 \\
\hline & & Morganella morgani & 1 & 12.5 \\
\hline & & Psudomonas aeruginosa & 1 & 12.5 \\
\hline & & Extended-spectrum beta-lactamase & 1 & 12.5 \\
\hline & & Staphylococcus aureus & 3 & 37.5 \\
\hline \multirow[t]{12}{*}{ Male } & \multirow[t]{9}{*}{$<65$ years } & Acinetobacter baumanni complex & 1 & 9.1 \\
\hline & & Eikenella corrodens & 1 & 9.1 \\
\hline & & Enterococcus faecalis & 1 & 9.1 \\
\hline & & Morganella morgani & 2 & 18.2 \\
\hline & & Proteus mirabilis & 1 & 9.1 \\
\hline & & Psudomonas aeruginosa & 1 & 9.1 \\
\hline & & Staphylococcus aureus & 1 & 9.1 \\
\hline & & Streptococcus dysgalactiae sp. equisimilis & 1 & 9.1 \\
\hline & & Streptococcus mitis & 1 & 9.1 \\
\hline & \multirow[t]{3}{*}{$\geq 65$ years } & Staphylococcus aureus & 1 & 33.3 \\
\hline & & Staphylococcus haemoliticus & 1 & 33.3 \\
\hline & & Streptococcus agalactia & 1 & 33.3 \\
\hline
\end{tabular}

(range: $5.4-14.7 \%$ ). Median creatinine value was 1.00 $\mathrm{mg} / \mathrm{dL}$. Urinary albumin level was measured in $62.5 \%$ of cases, and median value was $115.5 \mathrm{mg} / \mathrm{dL}$ (range: 9-2785 mg/dL). Mean CKD-EPI level was $75 \pm 27.34$ $\mathrm{mL} / \mathrm{min} / \mathrm{I} .73 \mathrm{~m}^{2}$ (range: II-I30 mL/min/l.73 $\mathrm{m}^{2}$ ). CKD-EPI levels were $<15 \mathrm{~mL} / \mathrm{min} / \mathrm{I} .73 \mathrm{~m}^{2}$ in I patient (3.1\%), $15-29 \mathrm{~mL} / \mathrm{min} / 1.73 \mathrm{~m}^{2}$ in I patient $(3.1 \%)$, $30-59 \mathrm{~mL} / \mathrm{min} / \mathrm{l} .73 \mathrm{~m}^{2}$ in 7 patients $(21.9 \%), 60-89$ $\mathrm{mL} / \mathrm{min} / \mathrm{I} .73 \mathrm{~m}^{2}$ in 13 patients $(40.6 \%)$, and $\geq 10 \mathrm{~mL} /$ $\mathrm{min} / 1.73 \mathrm{~m}^{2}$ in 10 patients (31.3\%). Bacterial growth was detected in wound cultures of 22 cases $(68.8 \%)$ and not present in 10 (31.3\%). Growth of multiple microorganisms was observed in wound cultures of 2 cases (Table 2).

In bacterial cultures of female patients under age of 65 years, growth of Candida glabrata $(n=1 ; 25 \%)$, Corynebacterium striatum $(n=1 ; 25 \%)$, Serratia marcescens $(n=I ; 25 \%)$, and Staphylococcus aureus $(n=1 ; 25 \%)$ were found. Staphylococcus aureus was also observed in 3 female patients (37.5\%) older than 65 years of age, as well as Citrobacter freundii $(n=1 ; 12.5 \%)$, Klebsialle pneumonia $(n=1 ; 12.5 \%)$,
Morganella morgani $(n=1 ; 12.5 \%)$, Psudomonas aeruginosa $(n=1 ; 12.5 \%)$ and Extended-spectrum betalactamase $(n=1 ; 12.5 \%)$.

In male patients younger than 65 years of age, growth of Acinetobacter baumanni complex ( $n=1 ; 9.1 \%)$, Eikenella corrodens $(n=1 ; 9.1 \%)$, Enterococcus faecalis $(n=1 ; 9.1 \%)$, Morganella morgagnii $(n=2 ; 18.2 \%)$, Proteus mirabilis ( $n=1 ; 9.1 \%$ ), Psudomonas aeruginosa $(n=1 ; 9.1 \%)$, Staphylococcus aureus $(n=1 ; 9.1 \%)$, Streptococcus dysgalactiae sp. equisimilis $(n=1$; $9.1 \%)$, and Streptococcus mitis $(n=1 ; 9.1 \%)$ were observed on bacterial culture media. In males patients 65 years of age or older, Staphylococcus aureus $(n=1$; $33.3 \%)$, Staphylococcus haemoliticus $(n=1 ; 33.3 \%)$, and Streptococcus agalactia $(n=I ; 33.3 \%)$ were found (Table 2).

A statistically significant difference was not found in growth rates of microorganisms based on mean age or distribution of genders ( $p>0.05)$ (Table 3 ).

Groupings based on CKD-EPI level revealed statistically significant differences in mean age $(p=0.028$; 
Table 3. Evaluation of parameters based on bacterial growth

\begin{tabular}{|c|c|c|c|c|c|c|c|}
\hline & \multicolumn{6}{|c|}{ Growth of microorganism } & \multirow[t]{3}{*}{$\mathrm{p}$} \\
\hline & \multicolumn{3}{|c|}{ Present } & \multicolumn{3}{|c|}{ Absent } & \\
\hline & $\mathrm{n}$ & $\%$ & Mean \pm SD (Median) & $\mathrm{n}$ & $\%$ & Mean \pm SD (Median) & \\
\hline${ }^{1}$ Age (years) & & & $59.73 \pm 9.31$ & & & $57.5 \pm 12.62$ & 0.579 \\
\hline \multicolumn{8}{|l|}{${ }^{2}$ Gender } \\
\hline Female & 8 & 61.5 & & 5 & 38.5 & & 0.699 \\
\hline Male & 14 & 73.7 & & 5 & 26.3 & & \\
\hline${ }^{3} \mathrm{C}$-reactive protein & & & $6.91 \pm 6.39(4.5)$ & & & $1.3 \pm 1.01(\% 1.3)$ & $0.018^{*}$ \\
\hline
\end{tabular}

${ }^{1}$ Student's t-test; ${ }^{2}$ Fisher's exact test; ${ }^{3}$ Mann-Whitney U test; ${ }^{*} p<0.05$. SD: Standard deviation.

Table 4. Evaluation of parameters based on CKD-EPI groups

\begin{tabular}{|c|c|c|c|c|}
\hline & \multicolumn{3}{|c|}{ CKD-EPI Group } & \multirow[t]{2}{*}{$\mathrm{p}$} \\
\hline & $\leq 59$ & $60-89$ & $\geq 90$ & \\
\hline Age (years), (mean \pm SD) & $64.56 \pm 10.26$ & $60.23 \pm 7.76$ & $52.5 \pm 10.55$ & $0.028^{*}$ \\
\hline \multicolumn{5}{|l|}{${ }^{2}$ Gender, n (\%) } \\
\hline Female & $4(30.8)$ & $5(38.5)$ & $4(30.8)$ & 1.00 \\
\hline Male & $5(26.3)$ & $8(42.1)$ & $6(31.6)$ & \\
\hline 'Duration of diabetes (years), (Mean \pm SD) & $21.78 \pm 8.26$ & $14.62 \pm 5.33$ & $11 \pm 3.2$ & $0.001^{* *}$ \\
\hline 'Glycated hemoglobin (Mean \pm SD) & $7.67 \pm 2.874$ & $9.26 \pm 1.83$ & $9.9 \pm 1.9$ & 0.083 \\
\hline \multicolumn{5}{|l|}{${ }^{3}$ Albuminuria $(n=20)$} \\
\hline Median (min.-max.) & $234(19-1124)$ & $126(9-2785)$ & $57(33-258)$ & 0.389 \\
\hline \multicolumn{5}{|l|}{${ }^{3}$ Albuminuria/Creatinine $(n=20)$, } \\
\hline Median (min.-max.) & $86.6(17.1-1021.8)$ & $119.2(11.7-2486)$ & $81.4(39.3-385)$ & 0.459 \\
\hline
\end{tabular}

$\mathrm{p}<0.05)$. In pairwise comparisons performed to find the group responsible for the statistically significant intergroup difference, mean age of patients with CKD-EPI level of $\leq 59 \mathrm{~mL} / \mathrm{min} / 1.73 \mathrm{~m}^{2}$ was found to be statistically significantly higher than those with CKD-EPI level of $\geq 90 \mathrm{~mL} / \mathrm{min} / \mathrm{l} .73 \mathrm{~m}^{2}(p=0.024$; $\mathrm{P}<0.05)$. No statistically significant difference was seen between other CKD-EPI groups on basis of mean age or distribution of male and female patients $(p>0.05)$.

Mean duration of diabetes differed statistically significantly between CKD-EPI groups $(p=0.001 ; p<0.01)$. In pairwise comparisons performed to determine the group responsible for the statistically significant intergroup difference, mean duration in patients with CKD-EPI levels of $\leq 59 \mathrm{~mL} / \mathrm{min} / 1.73 \mathrm{~m}^{2}$ was found to be statistically significantly higher than those with CKD-EPI levels of $\geq 90 \mathrm{~mL} / \mathrm{min} / 1.73 \mathrm{~m}^{2}(p=0.012$; $\mathrm{p}<0.05)$.

No statistically significant difference was detected between other CKD-EPI groups with regard to mean duration, $\mathrm{HbAIC}$ levels, urine albumin levels, urine albumin/creatinine ratios ( $p>0.05)$ (Table 4).

Growth of various microorganisms was observed in patients according to CKD-EPI level as follows: $<15$ $\mathrm{mL} / \mathrm{min} / \mathrm{l} .73 \mathrm{~m}^{2}$ : Candida glabrata $(\mathrm{n}=\mathrm{I}$; 100\%); I5-29 $\mathrm{mL} / \mathrm{min} / \mathrm{l} .73 \mathrm{~m}^{2}$ : Enterococcus faecalis $(\mathrm{n}=\mathrm{l} ; 100 \%)$; 30-59 mL/min/l.73 m²: Acinetobacter baumanii $(n=I$; $20 \%)$, Corynebacterium striatum $(n=l ; 20 \%)$, Serratia marcescens $(n=I ; 20 \%)$, Staphylococcus aureus, $(n=I ; 20 \%)$, Staphylococcus haemolyticus $(n=I ; 20 \%)$; $\geq 90 \mathrm{~mL} / \mathrm{min} / 1.73 \mathrm{~m}^{2}$ : Eikenella corrodens $(\mathrm{n}=\mathrm{I} ; 20 \%)$, 
Table 5. Distribution of microorganisms found according to CKD-EPI group

\begin{tabular}{llcc}
\hline CKD-EPI group & Microorganism & $\mathrm{n}$ & $\%$ \\
\hline$<15\left(\mathrm{~mL} / \mathrm{min} / 1.73 \mathrm{~m}^{2}\right)$ & Candida glabrata & 1 & 100 \\
$15-29\left(\mathrm{~mL} / \mathrm{min} / 1.73 \mathrm{~m}^{2}\right)$ & Enterococcus faecalis & 1 & 100 \\
$30-59\left(\mathrm{~mL} / \mathrm{min} / 1.73 \mathrm{~m}^{2}\right)$ & Acinetobacter baumanni complex & 1 & 20 \\
& Corynebacterium striatum & 1 & 20 \\
& Serratia marcecens & 1 & 20 \\
& Staphylococcus aureus & 1 & 20 \\
& Staphylococcus haemoliticus & 1 & 20 \\
$60-89\left(\mathrm{~mL} / \mathrm{min} / 1.73 \mathrm{~m}^{2}\right)$ & Citrobacter freundii & 1 & 7.1 \\
& Klebsialle pneumonia & 1 & 7.1 \\
& Morganella morgani & 2 & 14.3 \\
& Psudomonas aeruginosa & 2 & 14.3 \\
& Proteus mirabilis & 1 & 7.1 \\
& Extended-spectrum beta-lactamase & 1 & 7.1 \\
& Serratia marcecens & 1 & 7.1 \\
& Staphylococcus aureus & 4 & 7.1 \\
& Streptococcus dysgalactiae sp equisimilis & 1 & 28.6 \\
& Eikenella corrodens & 1 & 20 \\
& Morganella morgani & 1 & 20 \\
& Staphylococcus aureus & 1 & 20 \\
& Streptococcus agalactia & 1 & 20 \\
& Streptococcus mitis & 1 & 20 \\
\hline
\end{tabular}

Table 6. Evaluation of bacterial growth according to CKD-EPI group

\begin{tabular}{|c|c|c|c|c|c|c|c|}
\hline & \multicolumn{6}{|c|}{ CKD-EPI Group } & \multirow[t]{3}{*}{$\mathrm{p}$} \\
\hline & \multicolumn{2}{|c|}{$\leq 59$} & \multicolumn{2}{|c|}{$60-89$} & \multicolumn{2}{|c|}{$>90$} & \\
\hline & $\mathrm{n}$ & $\%$ & $\mathrm{n}$ & $\%$ & $\mathrm{n}$ & $\%$ & \\
\hline \multicolumn{8}{|l|}{ Growth } \\
\hline Present & 6 & 66.7 & 11 & 84.6 & 5 & 50 & 0.204 \\
\hline Absent & 3 & 33.3 & 2 & 15.4 & 5 & 50 & \\
\hline
\end{tabular}

Fisher's exact test.

Morganella morgagnii $(n=1 ; 20 \%)$, Staphylococcus aureus $(n=1 ; 20 \%)$, Streptococcus agalactiae $(n=1 ; 20 \%)$, Streptococcus mitis, $(n=1 ; 20 \%)($ Table 5, 6).

A statistically significant difference was not found between CKD-EPI groups with respect to bacterial growth $(p>0.05)$.

\section{DISCUSSION}

According to national population estimates, prevalence of DM in 2010 was 285 million patients worl- dwide aged between $20-79$ years, and this number is expected to rise to estimated 439 million by $2030 .{ }^{[4]}$ Several long-term complications may may occur, including DN, the most lethal, and increased urine albumin is an alarming sign of renal dysfunction or renal nephropathy. Renal dysfunction develops in $20-40 \%$ of all diabetic patients. ${ }^{[5]}$

Microalbuminuria is defined as creatinine levels of $\geq 30$ $\mathrm{mg}, 20 \mu \mathrm{g} / \mathrm{min}$ or $\geq 30 \mu / \mathrm{mg}$ creatinine. Prevalence of microalbuminuria increases in direct correlation with 
duration of DM, age, glycemic level, cardiovascular risk factors (e.g., hypertension, smoking, hyperlipidemia, and male gender), ethnic origin (black race), and renal disease. ${ }^{[6]}$ Microalbuminuria is associated with nephropathy, retinopathy, and cardiovascular disease. There is thought to be strong relationship between years since diagnosis, smoking status, and microalbuminuria in development of DF ulcer. Therefore, microalbuminuria has been accepted as an important indicator of risk for development of DF. ${ }^{[7]}$

In the present study, 20 of 32 cases were evaluated as for the presence of albuminuria. Consistent with the literature, urinary albumin levels in cases with DF were between 9 and $2785 \mathrm{mg} / \mathrm{dL}$ (median: $115.5 \mathrm{mg} /$ $\mathrm{dL})$. Still in accordance with literature findings, statistically significant difference was found in mean age between CKD-EPI groups ( $p=0.028$; $p<0.05)$. Pairwise studies revealed mean age of cases with CKD-EPI level of $\leq 59 \mathrm{~mL} / \mathrm{min} / 1.73 \mathrm{~m}^{2}$ was statistically significantly higher than that of cases with CKD-EPI level of $\geq 90 \mathrm{~mL} / \mathrm{min} / 1.73 \mathrm{~m}^{2}(p=0.024 ; p<0.05)$. Mean duration of diabetes of patients with CKD-EPI level of $\leq 59 \mathrm{~mL} / \mathrm{min} / \mathrm{l} .73 \mathrm{~m}^{2}$ was statistically significantly higher than that of the cases with CKD-EPI level of $\geq 90 \mathrm{~mL} / \mathrm{min} / 1.73 \mathrm{~m}^{2}(p=0.012 ; p<0.05)$.

Diabetic foot ulcer is seen in $15 \%$ of diabetic patients. As a reflection of interest, scientific papers on DF have increased from $0.7 \%$ in the $1980-88$ period to more than $2.7 \%$ between 1998 and $2004 .^{[8]}$

Classical triad of DF ulcer consists of infection, neuropathy, and ischemia. Impaired metabolic mechanisms, infection, decrease in response to cellular and growth factors, decreased peripheral blood flow, and angiogenesis impair wound healing. Deformation of peripheral nerves, ulcerations, and, eventually, gangrene develop. Hyperglycemia, increase in aldose reductase, sorbitol dehydrogenase, with ensuing accumulation of sorbitol, and increase in fructose in blood lead to decrease in inositol in nerve cells. Result is slowing of nerve conduction velocity, neuropathic changes, and increase in proinflammatory cytokines. Consequently, these processes affect chemotactic and intracellular apoptotic functions of nuclear leucocytes and have role in immunopathy and vasculopathy by means of inducing endothelial cell dysfunction. ${ }^{[9-11]}$

Cases of DF constitute large number of amputations performed for non-traumatic etiology in the United States of America, and it has been reported that 22\% to $42 \%$ of these amputated patients underwent a second amputation within 2 or 3 years. However, nearly $85 \%$ of amputations can be prevented with early and appropriate treatment. ${ }^{[12-14]}$

In a multidisciplinary study conducted in Turkey between $201 \mathrm{I}$ and 2013 of 455 cases of patients with diabetic foot infections, Gram-negative microorganisms were isolated most frequently. Pseudomonas aeruginosa was most common, followed by Esherichia coli. Among Gram-positive bacteria found, methicillin-sensitive Staphylococcus aureus was isolated.

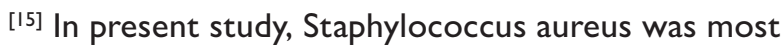
common bacteria detected among all participants. We think that multidisciplinary design of study and number of cases may be responsible for this difference. The most frequently isolated microorganism in patients with CKD-EPI level between 60-89 mL/dk./ $\mathrm{m}^{2}$ was Staphylococcus aureus, followed by Morganella morganii, and Pseudomanos aeruginosa, in order of decreasing frequency. In other CKD-EPI groups, microorganisms were distributed equally.

DF infections should be treated using a multidisciplinary approach, and narrow-spectrum antibiotics effective against most frequently encountered pathogens should be selected for empirical antibiotherapy. Severity of infection, presence of vascular disease, and microorganisms resistant to antibiotics should be taken into consideration. Generally, for superficial infections, broad-spectrum antibiotics effective against aerobic and Gram-positive cocci are first preference; in cases of serious infection, broad-spectrum antibiotics effective against Gram-negative and anaerobic microorganisms should be selected. ${ }^{[16,17]}$

In conclusion, DM can become a fatal disease because of its microvascular and macrovascular complications. While monitoring the disease, microalbuminuria warns the physician of development of microvascular complications, and these complications should be investigated during routine follow-up visits. Early diagnosis of neuropathy, which plays a role in the development of $D F$, and consequently the selection of appropriate treatment and shoes, is important issue. Great variety of microorganisms that may be found is one of the factors that complicate treatment success. Initiation of treatment at an early stage with appropriately selected empirical antibiotherapy is very effective in prevention of complications and healing of the wound site.

Therefore, it is critically important to raise aware- 
ness of patients about need for compliance with routine treatment and follow-up schedule in order to prevent complications and preserve quality of life.

\section{Conflict of interest}

None declared.

\section{REFERENCES}

1. Mogensen CE, Christensen CK, Vittinghus E. The stages in diabetic renal disease. With emphasis on the stage of incipient diabetic nephropathy. Diabetes 1983;32 Suppl 2:64-78.

2. Busby DE, Bakris GL. Comparison of commonly used assays for the detection of microalbuminuria. J Clin Hypertens (Greenwich) 2004;6(11 Suppl 3):8-12.

3. Jensen JS. Renal and systemic transvascular albumin leakage in severe atherosclerosis. Arterioscler Thromb Vasc Biol 1995;15:1324-9.

4. Shaw JE, Sicree RA, Zimmet PZ. Global estimates of the prevalence of diabetes for 2010 and 2030. Diabetes Res Clin Pract 2010;87:4-14.

5. Shahid M, Baig S, Zubariri A. Microalbuminuria and Status of diabetic nephropathy in low socioeconomic sect of Karachi. European Journal of Biotechnology and Bioscience 2015;3:28-30.

6. Warram JH, Gearin G, Laffel L, Krolewski AS. Effect of duration of type I diabetes on the prevalence of stages of diabetic nephropathy defined by urinary albumin/creatinine ratio. J Am Soc Nephrol 1996;7:930-7.

7. Guerrero-Romero F, Rodríguez-Morán M. Relationship of microal- buminuria with the diabetic foot ulcers in type II diabetes. J Diabetes Complications 1998;12:193-6.

8. Boulton AJ. The diabetic foot: from art to science. The $18^{\text {th }}$ Camillo Golgi lecture. Diabetologia 2004;47:1343-53.

9. Brem H, Tomic-Canic M. Cellular and molecular basis of wound healing in diabetes. J Clin Invest 2007;117:1219-22.

10. Clayton W, Elcasy TA. A Review of the Pathophysiology, Classification and Treatment of Foot Ulcers in Diabetic Patients. Clin Diabetes 2009;27:52-8.

11. Singh S, Pai DR, Yuhhui C. Diabetic Foot Ulcer-Diagnosis and Management. Clin Res Foot Ankle 2013;1:3.

12. Örmen B, Türker N, Vardar İ, Coşkun NA, Kaptan F, Ural S. Clinical and Bacteriological Evaluation of Diabetic Foot Infections. Turkish Journal of Infection 2007;21:65-9.

13. Dökmetaş İ, Dökmetaş HS, Şencan M. Diabetic Foot Infections. Flora 1999;4:3-8.

14. Armstrong DG, Lavery LA. Diabetic foot ulcers: prevention, diagnosis and classification. Am Fam Physician 1998;57:1325-38.

15. Saltoglu N, Yemisen M, Ergonul O, Kadanali A, Karagoz G, Batirel A, et al. Predictors for limb loss among patient with diabetic foot infections: an observational retrospective multicentric study in Turkey. Clin Microbiol Infect 2015;21:659-64.

16. Cunha BA. Antibiotic selection for diabetic foot infections: a review. J Foot Ankle Surg 2000;39:253-7.

17. Lipsky BA, Berendt AR, Deery HG, Embil JM, Joseph WS, Karchmer AW, et al. Diagnosis and treatment of diabetic foot infections. Clin Infect Dis 2004;39:885-910.

\section{Diyabetik Ayak Tanılı 32 Olgunun Bakteriyolojik ve Klinik Değerlendirilmesi}

Amaç: Bu çalışmanın temel amacı diyabetik ayak (DA) tanısı alan hastaların klinik ve laboratuvar özelliklerini araştırarak antibiyotik tedavisi ve klinik takip seçimine yardımcı olmaktır. Diyabetik ayak, böbrek komplikasyonları ve hastalıkların etki mekanizması arasındaki potansiyel ilişki incelendi.

Gereç ve Yöntem: Çalışmaya 20I4-20I5 tarihleri arasında dahiliye polikliniğinde DA nedeni ile izlenen toplam 32 olgu alındı. Hastaların tıbbi kayıtlarından incelenerek geriye dönük olarak lipid düzeyleri, mikroalbüminüri, mikroalbümin/kreatinin oranı, kreatinin klirensi (Chronic Kidney Disease Epidemiology Collaboration [CKD-EPI] ile formülize edilerek), HbAIc düzeyi kaydedildi.

Bulgular: Çalışma I3'ü kadın (\%40.6), I9'u erkek (\%59.4) toplam 32 olgu ile yapıldı. Olguların yaşları 32 ile 88 yıl arasında değişmekte olup, median değeri 58.5 yıldı. Olguların diyabet yaşları beş ile kırk yıl arasında değişmekte olup, ortalaması $15.5 \pm 7.06$ yıl, HbAlc düzeyleri 5.4 ile I4.7 arasında değişmekte olup, ortalaması $9.01 \pm 2.26$ idi. Olguların CKD-EPI düzeyleri II ile I30 arasında değişmekte olup, ortalaması $75 \pm 27.34$ 'tü. Olguların 22'sinde (\%68.8) mikroorganizma üremesi görülürken, I0'unda (\%3।.3) görülmedi. Olguların ikisinde (\%6.3) birden fazla mikroorganizma üremişti.

Sonuç: Yaş ve cinsiyete göre etken mikroorganizma incelendiğinde en çok Gram (+) kok grubu bakterilerin ürediği görüldü. CKD-EPI grupları arasında diyabet yaşı ortalamaları açısından anlamlı farklıık saptanmadı $(p=0.00 I ; p<0.0 I)$. CKD-EPI'ye göre üreyen mikroorganizmalara bakıldığında ise; $60-89 \mathrm{~mL} / \mathrm{dk} / \mathrm{m}^{2}$ arasında olan olgularda en çok üreyen mikroorganizma Staphylococcus aureus olarak görülmektedir.

Anahtar Sözcükler: Bakteri; CKD-EPI; diyabetik ayak; mikroalbüminüri. 